\title{
Repensando a práxis educacional: breve olhar sobre os recursos educacionais abertos
}

Rethinking the educational praxis: a brief look about open

educational resources

Danilo Meira Leite*

José Amilton Latanza**

\section{Santana, Bianca; Rossini, Carolina; Pretto, Nelson de Luca (Org.) Recursos Educacionais Abertos: práticas colaborativas e políticas públicas Salvador: Ed. UFBA; São Paulo: Casa da Cultura Digital, 2012. 246p.}

Onze artigos curtos e cinco entrevistas de autores das mais variadas frentes e formações compõem o livro Recursos Educacionais Abertos: práticas colaborativas e políticas públicas, que se apresenta como uma espécie de manual para o uso de recursos educacionais abertos (REA) em uma educação básica de qualidade. A publicação está dividida em três partes - reflexões teóricas, experiências, e depoimentos e entrevistas - e está disponível online no link: www.livrorea.net.br/livro/home.html. Organizado por Bianca Santana, Carolina Rossini e Nelson de Luca Pretto, o livro parte do pressuposto de que o ensino básico, tanto quanto o superior, necessita de reformas. Essas reformas devem ultrapassar as concepções pedagógicas "tradicionais", ou seja, devem promover uma reflexão aberta e integradora, atualizando a prática docente em conformidade com uma sociedade pós-moderna, em que as tecnologias modificam a interação entre as pessoas no tempo e no espaço e, consequentemente, o modus operandi do aprendizado. A educação aberta constitui elemento central da obra e se apresenta como um exercício de compreensão da liberdade da práxis educacional, como uma educação escolar para além dos muros e grades, na qual o consumidor-aluno se torne um produtor-cidadão.

\footnotetext{
${ }^{\star}$ Graduando em História, Universidade Estadual de Londrina (UEL), bolsista Pibic-CNPq. danilomeira7@yahoo.com.br

${ }^{*}$ Graduado em História, Universidade Estadual de Londrina (UEL), bolsista PDE/Paraná. jalcom@ seed.pr.br
} 
Tel Amiel, no princípio de seu artigo "Educação aberta: configurando ambientes, práticas e recursos educacionais" - o primeiro do livro -, questiona (p.18): "o acesso à escola está crescendo, mas podemos dizer o mesmo do acesso à educação?”. Para Amiel, a configuração estrutural da escola não permite uma prática livre de ensino, o que o autor define como:

Fomentar (ou ter à disposição) por meio de práticas, recursos e ambientes abertos, variadas configurações de ensino e aprendizagem, mesmo quando essas aparentam redundância, reconhecendo a pluralidade de contextos e as possibilidades educacionais para o aprendizado ao longo da vida. (p.18-19)

Para Amiel (p.21), com as tecnologias de informação e comunicação (TIC), a relação ensino-aprendizagem poderia ocorrer de forma muito mais livre e ampla, pois há grande crescimento de oportunidades de aprendizado, o que não implica "sepultar as instituições que existem", mas sim buscar a (des) construção e o acesso de maneira mais ampla possível a uma educação de qualidade para todos.

Carolina Rossini e Cristiana Gonzalez, coautoras do segundo artigo, intitulado "REA: o debate em política pública e as oportunidades para o mercado", fazem uma breve apresentação de suas formas de olhar os REA, discutem as iniciativas e financiamentos governamentais, comparam o Brasil com outros países e introduzem o debate sobre modelos de negócios abertos em REA, como, por exemplo, os mercados editoriais. Segundo as autoras, o "centro do negócio das editoras é ... o controle sobre o direito autoral dos livros” (p.46). Esse controle ocorre por meio de contratos de cessão de direitos autorais, que não raramente lesam o direito dos autores (p.52). O caminho legal em prol da desarticulação desse monopólio é o tema do artigo.

No artigo intitulado "Educação aberta: histórico, práticas e o contexto dos recursos educacionais abertos", Andreia Inamorato dos Santos parte do conceito de educação aberta, discutindo as definições desse conceito e o seu respectivo desenvolvimento e popularização na universidade (p.71). Destarte, a terminologia da área é seu tema e uma "webografia", um dos elementos distintivos do artigo.

O quarto artigo do livro, "Professores-autores em rede", escrito por Nelson de Luca Pretto, consiste num ensaio acerca do tipo de produção docente no Brasil e seu modus operandi a partir do advento das TIC. Nesse intuito, 
Pretto tece uma breve história do livro didático, estabelecendo um paralelo entre os livros didáticos tradicionais, os meios de comunicação e o uso dos REA voltados à prática educativa. Para o autor, a produção de conhecimentos deve partir de uma perspectiva multiculturalista que abarque com um olhar de alteridade o "outro" em rede.

O livro ainda traz uma seção especial, denominada "depoimento e experiência”. Nela, Bianca Santana inicia seu texto (p.133) com a questão da inserção dos materiais digitais (lousa digital e tablets, entre outros) em colégios da capital do estado de São Paulo, da rede privada e pública de ensino, no ano de 2012. Para a autora, o uso desses recursos é intrínseco à licença que esses materiais detêm, pois, se estão "sob a frase 'todos os direitos reservados', não podem ser utilizados para qualquer finalidade, nem gerar novos usos, ou ser remixados em novos produtos, ou ser distribuídos para ter seu acesso ampliado" (p.140).

Priscila Gonsales, no artigo "Aberturas e rupturas na formação dos professores”, defende a formação continuada dos professores da rede pública e privada de ensino no uso das TIC e assinala que a experiência de trabalhar por 10 anos no projeto Educared ${ }^{1}$ (2001-2010) foi muito importante para uma conscientização sobre o tema (p.143-144). Esse trabalho proporcionou a criação de outro projeto, voltado igualmente para a área educacional, o Educadigital, ${ }^{2}$ que visa a capacitação dos educadores em REA, "pois são eles/as quem detêm o poder de transformação da sua prática em REA” (p.149).

Outro autor da coletânea de artigos, Rafael Reinehr, defende a educação enquanto autônoma, e o cidadão como um produtor de REA. Para o ativista político na área da cultura livre, cujo artigo é intitulado "Recursos educacionais abertos na aprendizagem informal e no autodidatismo", a busca pelo conhecimento por vias não formais, "desescolarizadas", libera o discente do sufocamento da criatividade que ocorre dentro dos muros da escola. Reinehr indica também repositórios digitais para busca e pesquisa de conteúdos e saberes, além de sites e demais veículos de informação disponíveis para o aprendizado de forma ampla e aberta (p.158-172). Conclui, com base em Eduardo Galeano, que as utopias são semelhantes às formulações REA, pois não devemos parar de sonhar em busca da educação cada vez melhor e de qualidade (p.175).

O artigo "Wikimedia Brasil e recursos educacionais abertos" apresenta a opinião de Heloisa Pait, Everton Z. Alvarenga e Raul C. Nascimento no intuito 
de difundir uma visão colaborativa e inclusiva de conhecimentos no Brasil (p.177). Pait (p.180) relembra sua experiência com a ferramenta Moodle, criada pelo australiano Martin Dougiamas, como uma forma de expansão do ensino. Alvarenga propõe uma reflexão acerca da rede social Stoa, que envolve estudantes, professores, funcionários e ex-alunos da Universidade de São Paulo (USP), com o fim de promover a produção de REA e a cultura colaborativa. Raul Nascimento busca, por meio da Wikimedia, aproximar o conhecimento daqueles que não detêm poder aquisitivo para compra de livros a fim de se enriquecer intelectualmente.

Como se pode notar, mais do que teóricos, os autores do trabalho atuam como ativistas da causa de uma educação mais aberta, bem como de uma internet (se não uma cultura) mais livre. O livro, que foi publicado em 2012, está disponível em formato aberto na rede. Desde seu lançamento, passa por mudanças constantes, implementadas à medida que seus leitores enviam recomendações aos autores por meio do site. Nesse espírito, o autor Tel Amiel, quando inquirido sobre a atualidade do tema e a posição do Brasil em relação aos demais países quanto à produção de REA, destaca:

Eu não saberia comparar REA, porque o desenvolvimento tem sido rápido no mundo todo e é difícil saber o que acontece em todo lugar; o que eu diria é que, no Brasil, estamos começando a ter mais consciência do que é REA, e precisamos ainda, muito, de sensibilização sobre o tema. Recentemente finalizamos uma fase 1 de um mapa de iniciativas REA no ensino básico na América Latina (www. mira.org.br). O que identificamos é que há ainda muito pouco que se enquadraria numa definição formal de REA. Precisamos construir mais espaços e recursos para o ensino básico, em português. No entanto, o que temos visto é que, quando apresentadas ao conceito, pessoas de todos os tipos de engajamento se interessam por algum aspecto de REA. Ao mesmo tempo é preciso continuar trabalhando na construção de esquemas de incentivo e políticas institucionais que valorizem REA (na ciência aberta, na produção de recursos abertos, nas chamadas de editais de agências de fomento etc.).3

Nesse ensejo, não será demais assinalar que a educação, assim como os poemas de Manoel de Barros, é feita de ideações. 


\section{NOTAS}

${ }^{1}$ Projeto de produção de conteúdo e troca de práticas educativas fomentado pela Fundação Telefônica: www.educared.org/global/educared/queeseducared_br.

2 "O IED é uma organização de direito privado sem fins lucrativos que tem como foco promover a integração da cultura digital aos diferentes espaços e ambientes educativos de caráter público, de forma a gerar novas oportunidades de aprendizagem para o desenvolvimento pleno do ser humano." http://educadigital.org.br/site/?page_id=10.

${ }^{3}$ E-mail em resposta aos autores da resenha, 10 maio 2014.

Resenha recebida em 30 de maio de 2014. Aprovada em 27 de junho de 2014. 